University of Pennsylvania Law School

Penn Law: Legal Scholarship Repository

Faculty Scholarship

$7-31-2006$

\title{
Federalism and Private International Law: Implementing the Hague Choice of Court Convention in the United States
}

Stephen B. Burbank

U of Penn Law School, sburbank@law.upenn.edu

Follow this and additional works at: http://scholarship.law.upenn.edu/faculty_scholarship

Part of the Courts Commons, International Law Commons, and the Jurisdiction Commons

\section{Recommended Citation}

Burbank, Stephen B., "Federalism and Private International Law: Implementing the Hague Choice of Court Convention in the United States" (2006). Faculty Scholarship. Paper 97.

http://scholarship.law.upenn.edu/faculty_scholarship/97 


\title{
FEDERALISM AND PRIVATE INTERNATIONAL LAW: IMPLEMENTING THE HAGUE CHOICE OF COURT CONVENTION IN THE UNITED STATES
}

\author{
Stephen B. Burbank†
}

\begin{abstract}
Federalism is important in the United States. It is also important that the United States be able to participate effectively in a global economy and that those charged with the conduct of the country's foreign affairs be able to make, and that the country abide by, international agreements that are designed to facilitate transnational commercial activity. The Hague Choice of Court Convention is one such agreement, the modest fruits of more than a decade of work in an international lawmaking effort that was initiated by the United States. However modest the fruits of the enterprise, the rest of the world is watching to see whether the United States ratifies, and how it implements, the Hague Convention.

Effective dispute resolution processes are critical to a well-functioning global economy, and effectiveness for this purpose requires, just as it does for a national or regional economy, generous recognition and enforcement of judgments. Key to such generosity, in turn, are acceptable jurisdiction standards and, experience has demonstrated, reciprocity. Finally, mutual assurance that reciprocity will in fact be forthcoming requires very considerable uniformity and certainty in the governing legal rules.

The Hague Convention leaves little room for variation or departure in standards for asserting jurisdiction or recognizing and enforcing judgments. Although there are good reasons to implement the treaty through legislation, the proposal that the uniform state law process be used for that purpose is not well considered. The history of domestic regulation does not provide strong normative support for state law to furnish the rules for jurisdiction and judgment recognition in international cases. Harmonization with abutting or intersecting state law norms, which is a legitimate concern in thinking about international private lawmaking on many subjects, is not generally a concern in connection with the law governing jurisdiction and judgment recognition. The Hague Convention appears to be an exception to that generalization with respect to jurisdiction, because choice of court clauses implicate contract law. Experience in the arbitration field suggests, however, that an attempt to harmonize would be a mistake, and the relevant state contract law is in any event underdeveloped and not uniform. Finally, federal implementation through legislation prescribing federal law that is mostly uniform, but a few provisions of which may borrow designated state law, would impose lower transaction and administrability costs, with no loss of accessibility, than would state implementation.
\end{abstract}




\section{Introduction}

A number of recent lawmaking initiatives, international and domestic, have put in focus questions concerning the roles that international, federal and state law can and should play as sources of authority and sources of rules in the United States for exercises of jurisdiction, and the recognition and enforcement of judgments, in international cases. In this article, I explore a subset of those questions by considering the domestic process that should be used to implement, and the domestic law that should be used to supplement, the Hague Convention on Choice of Court Agreements (the "Hague Convention"). ${ }^{1}$ In particular, I examine (1) the appropriateness and feasibility of a process that relies, in whole or part, on the states of the United States for this treaty's implementation, and (2) the appropriate relationship between federal and state law in filling its interstices, whatever implementation process is selected. I also hope to cast light on the choice between federal law (of the sort recently recommended by the American Law Institute) ${ }^{2}$ and state law (of the sort recently recommended by the Uniform Law Commissioners) ${ }^{3}$ for the recognition and enforcement of foreign-country judgments that are not covered by the Hague Convention.

The Hague Convention represents the modest but potentially useful remains of an ambitious effort, initiated by the United States in the early 1990's, that sought to craft a multilateral treaty providing the rules for jurisdiction and judgment recognition and enforcement in civil cases. The United States was concerned that, although foreign-country judgments were very liberally recognized and enforced here, American judgments did not receive a similar reception abroad. Our delegation also sought to solve the problem of discriminatory treatment of Americans in litigation abroad through foreign judgments based on

\section{(C) Stephen B. Burbank 2006}

$\dagger$ David Berger Professor for the Administration of Justice, University of Pennsylvania Law School. A preliminary version of this article was presented to the Conflict of Laws Section of the Association of American Law Schools in January 2006. Samuel Baumgartner, Kevin Clermont, Louis Pollak, Curtis Reitz, and Peter Trooboff provided helpful comments on a draft, and the author profited from discussions with Bill Woodward about the role of contract law in the enforcement of choice of forum clauses. Jie Yuan, Penn Law Class of 2006, provided excellent research assistance.

${ }^{1}$ Convention on Choice of Court Agreements, concluded June 30, 2005 [hereinafter Hague Convention], http://www.hcch.net/index_en.php?act=conventions.pdf\&cid=98. For recent commentary on the background and provisions of the Hague Convention, see Louise Ellen Teitz, The Hague Choice of Court Convention: Validating Party Autonomy and Providing an Alternative to Arbitration, 53 AM. J. CoMP. L. 543 (2005).

${ }^{2}$ See RECOGNITION AND ENFORCEMENT OF FOREIGN JUDGMENTS: ANALYSIS AND Proposed Federal Statute (Proposed Final Draft 2005) [hereinafter Ali Project].

${ }^{3}$ See Unif. Foreign-Country Money Judgments ReCognition Act (2005). 
grounds of jurisdiction that were avowedly exorbitant when deployed against others. The prospects for such treatment had increased with the expanding reach of provisions in the Brussels Convention authorizing, and requiring the recognition of judgments founded on, it. ${ }^{4}$

The effort to conclude a global jurisdiction and judgments convention foundered, in part, on the lack of a credible quid pro quo. Negotiators from the rest of the world perceived that they had little to gain in the area of judgment recognition and enforcement as a result of unilateral American generosity. ${ }^{5}$ They therefore viewed the negotiations as an opportunity to proscribe as exorbitant in international cases jurisdictional grounds - including general doing business jurisdiction -- that American negotiators, aware of opposition at home, were unwilling to surrender. ${ }^{6}$

${ }^{4}$ See Stephen B. Burbank, Jurisdictional Equilibration, the Proposed Hague Convention, and Progress in National Law, 49 AM. J. CoMP. L. 203, 232 (2001) [hereinafter Jurisdictional Equilibration]; Stephen B. Burbank, Federal Judgments Law: Sources of Authority and Sources of Rules, 70 TEXAs L. REV. 1551, 1572-73 (1992) [hereinafter Federal Judgments Law]; Arthur T. von Mehren, Recognition and Enforcement of Foreign Judgments: A New Approach for the Hague Conference?, 57 LAw \& CONTEMP. PROBS. 271, 278-79 (Summer 1994).

5 The

The problem with unilateral generosity is that it may weaken U.S. bargaining power when, other countries having chosen not to follow our example, it attempts to work out mutually acceptable agreements. That looms as a difficulty for the United States in pursuing a multilateral convention on the recognition and enforcement of foreign judgments.

Stephen B. Burbank, The Reluctant Partner: Making Procedural Law for International Civil Litigation, 57 LAW \& CONTEMP. PROBS. 103, 138-39 (Summer 1994) (footnotes omitted). For a discussion of the issues, see SAmuel P. BAumgartner, The Proposed Hague Convention ON JURISDICTION AND FOREIGN JUDGMENTS 6-9 (2003).

${ }^{6}$ See Stephen B. Burbank, Jurisdiction to Adjudicate: End of the Century or Beginning of the Millennium?, 7 TulanE J. INT'L \& COMP. L. 111, 119 (1999); Linda J. Silberman, Can the Hague Judgments Project Be Saved?: A Perspective from the United States, in A GLOBAL LAW OF JURISDICTION AND JUDGMENTS: LESSONS FROM THE HAGUE 177 (John J. Barceló III \& Kevin M. Clermont eds., 2002); Linda J. Silberman, Comparative Jurisdiction in the International Context: Will the Proposed Hague Judgments Convention Be Stalled?, 52 DEPAUL L. REV. 319 (2002). Other obstacles included "the force of constitutional change in Europe - the shift of competence from European Union member states to the European Community in Brussels - and the rise of the Internet economy and the resulting uncertainties caused by new business models, changing technology, and new commercial players.” Jeffrey D. Kovar, In Memoriam: Arthur T. Von Mehren, 119 HARV. L. REV. 1952, 1953 (2006). See also Ronald A. Brand, The 1999 Hague Preliminary Draft Convention Text on Jurisdiction

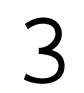


To the credit of negotiators on both sides of these issues, rather than giving up, they moderated their ambitions and worked out a treaty providing both uniform jurisdiction and recognition and enforcement standards for the adjudication of business-to-business disputes governed by exclusive choice of court clauses. The goal of this treaty is "to promote international trade and investment through enhanced judicial co-operation," and the chosen method is "an international legal regime that provides certainty and ensures the effectiveness of exclusive choice of court agreements between parties to commercial transactions and that governs the recognition and enforcement of judgments resulting from proceedings based on such agreements.",

\section{Is Implementing Legislation Necessary or Appropriate?}

It is for each country to determine the domestic processes appropriate (1) to reach a decision whether to ratify the Hague Convention and (2) if ratified, to implement it. ${ }^{8}$ On the

and Judgments: A View from the United States, 40 RIVISTA DI DIRITTO InTERNAZIONALE PRIVATO E ProcessuALE, Jan.-Mar. 2004, at 31, 31-32, 35.

${ }^{7}$ Hague Convention, supra note 1, pmbl. Since the die was cast in favor of prescribing standards for both jurisdiction and judgment recognition in the Brussels Convention of 1968, and given the role that jurisdictional anxiety played in sabotaging the effort to reach a simple judgments treaty between the United States and the United Kingdom in the ensuing decade, it has long been clear that successful international lawmaking on foreign-country judgment recognition and enforcement standards also requires agreement on international jurisdiction standards. The hope of the United States in the recently concluded initiative at The Hague was that the jurisdictional diversity necessarily implicated in a global treaty would permit successful negotiation of an instrument that departed from the Brussels model of a double convention by carving out some unregulated jurisdictional space in which Contracting States would be free to continue to operate under national jurisdiction and recognition law. See von Mehren, supra note 4. Both the pull of the Brussels model and the negotiating incentives and ambitions of other countries dashed that hope, but the history helps to understand the importance of both sets of provisions in the Hague Convention and the importance of uniform adherence to them by Contracting States.

8 In the absence of special agreement, it is ordinarily for the United States to decide how it will carry out its international obligations. Accordingly, the intention of the United States determines whether an agreement is to be self-executing in the United States or should await implementation by legislation or appropriate executive or administrative action.

RESTATEMENT (THIRD) OF THE FOREIGN RELATIONS LAW OF THE UNITED STATES $§ 111$, cmt. h (1987).

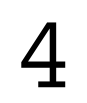


assumption that ratification will not be controversial, ${ }^{9}$ the first major choice for the United States would seem to be between viewing the treaty as self-executing, in which event it would require only Senate consent to become binding domestic law (once ratified and entering into force internationally), or as non-self-executing and thus also requiring implementing legislation.

The provisions of the Hague Convention appear to call for judicial enforcement, the hallmark of a self-executing treaty that directly preempts state law under the Supremacy Clause. ${ }^{10}$ Nor would the treaty "achieve what lies within the exclusive law-making power of Congress under the Constitution." ${ }^{11}$ Pointing in the other direction is the fact that a multilateral treaty may be less likely to yield a domestic interpretation that it is self-executing than a bilateral treaty. ${ }^{12}$ In any event, politics can trump general principles of treaty interpretation, and both the Senate, in giving consent to a treaty, and the Congress by resolution have claimed the power to require implementing legislation. ${ }^{13}$ Moreover, politics aside, the Hague Convention contains at least two pegs on which to hang arguments for implementing legislation, and some such legislation appears warranted in any event.

The Hague Convention specifically adverts to problems that may arise in, or as a result of, "non-unified legal systems." Thus, Article 28 permits a State to declare at the time of ratification "that the Convention shall extend to all its territorial units or only to one or more of

${ }^{9}$ This assumption might prove false if the analytically distinct issue of the mode of implementation proved controversial and if either the Senate or the Executive Branch chose to link consent/ratification and implementation.

${ }^{10}$ U.S. CONST. art. VI, cl. 2. In the United States a different principle is established. Our constitution declares a treaty to be the law of the land. It is, consequently, to be regarded in courts of justice as equivalent to an act of the legislature, whenever it operates of itself without the aid of any legislative provision. But when the terms of the stipulation import a contract, when either of the parties engages to perform a particular act, the treaty addresses itself to the political, not the judicial department; and the legislature must execute the contract before it can become a rule for the Court.

Foster v. Neilson, 27 U.S. (2 Pet.) 253, 314 (1829).

${ }^{11}$ Restatement (ThIRD), supra note 8 , § $111 \mathrm{cmt}$. i.

12 See United States v. Postal, 589 F.2d 862 ( $5^{\text {th }}$ Cir.), cert. denied, 444 U.S. 832 (1979). But see Carlos Manuel Vasquez, The Four Doctrines of Self-Executing Treaties, 89 AM. J. INT'L L. 695, 708 (1995) (criticizing Postal). As Professor Vasquez notes, "it is well accepted that some provisions of a treaty may be self-executing while others are not.” Id. at 709 (footnote omitted).

13 See RestATEMENT (ThIRD), supra note 8, § 111 (4)(b). These claims are not uncontroversial. See Vasquez, supra note 12, at 704-10. 
them," and to "modify this declaration by submitting another declaration at any time."14 This provision appears to be designed primarily for countries like Canada which lack constitutional power to bind their constituent states, but it could be adduced in the United States (which is not so disabled) as evidence of the acceptability, at least internationally, of ratification for less than the whole country through some process permitting state choice.

In addition, Article 25 of the Hague Convention seeks to accommodate the existence of "two or more systems of law apply[ing] in different territorial units with regard to any matter dealt with in this Convention” by affording freedom, where "appropriate," to interpret references to (1) "the law or procedure of a State," (2) "residence in a State," (3) "the court or courts of a State," and (4) "a connection with a State" as references to the "relevant territorial unit." 15 This provision would be germane in the United States even if the Hague Convention were regarded as a self-executing treaty. Opponents of self-executing treaties may, however, seize on the observation in the drafting history that implementing legislation could be used to provide "how 'appropriate' is to be understood" in Article 25. ${ }^{16}$

Whatever the effect of such provisions under United States treaty law, the Hague Convention undoubtedly presents a number of issues as to which, in the absence of implementing legislation, uncertainty is predictable, both here and abroad, about the governing law in the United States. An ex ante specification of the governing law for such issues is desirable both to reduce transaction costs and to promote the treaty's goals of certainty and uniformity. Thus, Article 5 confers jurisdiction pursuant to an exclusive choice of court agreement "unless the agreement is null and void under the law of that State," obligates courts of other Contracting States to suspend or dismiss proceedings unless, among other exceptions, "the agreement is null and void under the law of the State of the chosen court," "a party lacked the capacity to conclude the agreement under the law of the State of the court seised," or "giving effect to the agreement would lead to a manifest injustice or would be manifestly contrary to the public policy of the State of the court seised."18 The uncertainty that, for example, would attend an unguided determination by contracting parties or by a U.S. court under Article 5 whether the choice of a U.S. forum would be or was "null and void under the

${ }^{14}$ Hague Convention, supra note 1, art. 28. Cf. id. art. 33 (providing that denunciations "may be limited to certain territorial units of a non-unified legal system to which this convention applies”).

${ }^{15}$ Id. art. 25.

${ }^{16}$ Masato Dogauchi \& Trevor C. Hartley, Hague Conference on Private InT’L LaW, Preliminary Draft Convention on EXClusive Choice of Court Agreements: DrAFt REPORT, PREL. Doc. No. 26, at 47 n. 222 (2004), available at http:www.hcch.net/upload/wop/jdgm_pd26e.pdf. The comment perhaps reflected awareness that some countries with non-unified legal systems would have to put the treaty into effect by legislation, not the view that implementing legislation would be appropriate for all such countries.

${ }^{17}$ Hague Convention, supra note 1, art. 5(1).

${ }^{18}$ Id. art. 6(a)-(c). 
law of that State" probably pales in comparison with the uncertainty that would attend unguided determinations of that question by the courts of other Contracting States under Article 6.

Similarly, under Article 9's exceptions to the duty to recognize and enforce judgments, questions will predictably arise whether (1) "the agreement was null and void under the law of the State of the chosen court,"19 (2) "a party lacked capacity to conclude the agreement under the law of the requested State,"20 (3) service was effected "in a manner that is incompatible with fundamental principles of the requested State,"21 and (4) "recognition or enforcement would be manifestly incompatible with the public policy of the requested State, including situations where the specific proceedings leading to the judgment were incompatible with fundamental principles of procedural fairness of that State.”22 Neither contracting parties and disputants nor domestic and foreign courts should be left at sea concerning the U.S. law that provides the answers to those questions.

In addition, the Hague Convention permits Contracting States to make a number of choices that may be relevant in domestic decisions regarding implementation and the governing law and that should be made accessible in legislation. For example, the treaty enables Contracting States to opt out of the default rule that requires documents "be accompanied by a certified translation into an official language" by providing otherwise in domestic law. ${ }^{23}$ More important, it affords Contracting States the ability to make a number of declarations, including declarations preserving the ability to refuse to exercise jurisdiction when "there is no connection between that State and the parties or the dispute," 24 and to refuse to recognize or enforce judgments "if the parties were resident in the requested State, and the relationship of the parties and all other elements relevant to the dispute ... were connected only with the requested State." ${ }^{25}$ Contracting States are also empowered to declare that they will not apply the Hague Convention to specific matters, "clearly and precisely defined," in which they have a strong interest in remaining free of the treaty's obligations. ${ }^{26}$ Finally, the treaty confers the power to bring within the reach of its provisions on recognition and enforcement, by reciprocal declarations, judgments given by courts designated in non-exclusive choice of court agreements, in certain circumstances. ${ }^{27}$ Each of these choices requires careful study by the United States. Knowledge of the decisions made with respect to them should not require research in international legal materials, and such research would not in any event reveal the
${ }^{19}$ Id. art. 9(a).
${ }^{20}$ Id. art. 9(b).
${ }^{21}$ Id. art. 9(c)(ii).
${ }^{22}$ Id. art. 9(e).
${ }^{23}$ Id. art. 13(4).
${ }^{24}$ Id. art. 19.
${ }^{25}$ Id. art. 20.
${ }^{26}$ Id. art. 21.
${ }^{27}$ See id. art. 22. 
reasons for those decisions. Legislation and legislative history appear to be the best vehicles for informing courts and parties on these subjects.

\section{The Arguments for Implementation through Uniform State Law}

The prospect of legislation to implement the Hague Convention in the United States, whether or not such legislation is required, has already led some to call for a process that makes use of state law in general, and of uniform state law in particular, for that purpose. In a recently published article, my colleague, Professor Curtis Reitz, then chair of the National Conference of Commissioners on Uniform State Laws' International Legal Developments Committee, explores various possible intersections between state law and treaty law. ${ }^{28}$ While noting an unanswered domestic constitutional question surrounding use of the "Canada clause" to permit state governments "to decide whether or not to implement a convention," 29 Professor Reitz champions the use of uniform state law rather than (or, where necessary, in addition to) federal legislation for the purpose of implementing non-self-executing treaties. ${ }^{30}$

Central to this argument is the view that, in areas that for domestic purposes are traditionally governed by state law, the United States should, when appropriate, seek "soft law" rather than "hard law" in the treaties it negotiates, ${ }^{31}$ eschew self-executing treaties (by their nature federal law that preempts inconsistent state law), ${ }^{32}$ and rely on the uniform state law process of the Conference to achieve a level of state adoption sufficient to permit notification of ratification of the treaty. ${ }^{33}$ Professor Reitz maintains that this approach is preferable to federal legislation because it permits harmonization of treaty provisions with surrounding state law, and that it is preferable to self-executing treaties both for that reason and for reasons of accessibility. Moreover, he observes, in situations requiring expeditious implementation, the uniform law process could be backed up by federal default legislation (that would apply if state action were not secured by a prescribed date). ${ }^{34}$

${ }^{28}$ See Curtis R. Reitz, Globalization, International Legal Developments, and Uniform State Laws, 51 Loyola L. REV. 301 (2005).

${ }^{29} \mathrm{Id}$. at 318. See supra text following note 14.

${ }^{30}$ See id. at 318-27.

${ }^{31}$ See id. at 312-19.

"Hard law" proposals are proposals formulated so that, if implemented, the precise texts of the proposals become the law of the implementing government. ... "Soft law" proposals are proposals set out in the form of a model law or legislative guide, so that each implementing nation or state is free to design its own statutory texts.

Id. at 312-13 (footnotes omitted).

${ }^{32}$ See id. at 319-20.

${ }^{33}$ See id. at 320-27.

${ }^{34}$ See id. at 323-24. 
Professor Reitz asserts at the end of his article that implementation of the Hague Convention (together with two other planned conventions) "through state legislation seems to be the optimal course to follow," 35 noting that each of the three planned conventions "is closely related to an existing product of the Uniform State Laws Conference,” and arguing that "[a]s these negotiations begin, anticipation of future implementation by state legislation seems appropriate to all three developments." ${ }^{36}$ It is, therefore, not surprising that others associated with the Conference have also advocated implementation of the Hague Convention through uniform state legislation.

IV. The Extent of Federal Power and the Normative Implications of a History of State Regulation

In order to evaluate these arguments it is useful, first, to consider the respective powers of the federal government and the states with respect to the matters treated in the Hague Convention, and, second, to identify and evaluate the considerations that bear on the wise use of such powers. There can be no serious doubt about the power of Congress to enact legislation prescribing uniform federal rules for the recognition and enforcement of foreigncountry judgments and hence no doubt at all about the validity of a treaty, whether selfexecuting or not, that has the same effect. Viewed in isolation, the power of Congress to preempt state jurisdiction law in international cases - as by requiring state courts to entertain cases in which jurisdiction is founded only on the parties' choice of court agreement - is less clear, and it thus may be less clear whether the treaty power could be used to effect the same result. Notwithstanding changing attitudes toward federalism in domestic constitutional law, however, legislation implementing the Hague Convention's jurisdiction provisions would probably pass muster as falling within Congress' powers under the Necessary and Proper Clause. ${ }^{37}$ The main authority for that proposition is, after all, a case decided when federalism was a stronger brake on congressional action than it is today. ${ }^{38}$

${ }^{35}$ Id. at 327.

${ }^{36} \mathrm{Id}$.

${ }^{37}$ U.S. CONST. art I, § 8. But see Nicholas Quinn Rosenkrantz, Executing the Treaty Power, 118 Harv. L. Rev. 1867 (2005) (Congress can implement non-self-executing treaty by legislation only if it would have independent power to legislate). A federalism objection in this setting might in any event be academic, because consent "is a well recognized basis for the exercise of judicial jurisdiction" that "is customarily exercised by a court even in the absence of express statutory authority.” MODEL CHOICE OF FORUM ACT pref. note (1968), in 77 HANDBOOK OF THE NATIONAL CONFERENCE OF COMMISSIONERS ON UNIFORM STATE LAWS 219 (1968). See also Adrian Briggs, The Impact of Recent Judgments of the European Court on English Procedural Law and Practice 5, University of Oxford Faculty of Law Legal Studies Working Paper No 11/2006 (April 2006) < http://www.ssrn.com/link/oxford-legalstudies.html $>$ ("Submission to the court is a fundamental principle of jurisdictional competence.”).

${ }^{38}$ See Missouri v. Holland, 252 U.S. 416 (1920); CONGRESSIONAL RESEARCH SERVICE, TREATIES AND OTHER INTERNATIONAL AGREEMENTS: THE ROLE OF THE UNITED STATES 
Even if, however, the reach of implementing legislation were confined to the limits of domestic legislative power, it is noteworthy that, without the aid of a treaty, Congress has preempted state service of process law and at least some state jurisdiction law in international cases involving foreign states. ${ }^{39}$ Moreover, in this context it may be a mistake to consider the question of constitutional power to prescribe rules of jurisdiction for international cases in isolation. With simultaneous bargaining on jurisdiction and judgment recognition and enforcement now the norm in treaty making, a country acting unilaterally (i.e., in the absence

Senate, S. Prt. 106-71, $106^{\text {th }}$ Cong., 2d Sess. $65-67$ (2001); Restatement (THIRD), supra note $8, \S 302 \mathrm{cmt}$. d.

${ }^{39}$ See 28 U.S.C. §§ 1330, 1602-11 (2000) (codifying parts of the Foreign Sovereign Immunities Act of 1976). Section 1330(b) speaks only to personal jurisdiction in federal courts. Section 1604 does not appear to require state courts to assert jurisdiction when there is no immunity under federal law, although it clearly preempts state law authorizing personal jurisdiction when federal law provides immunity. See also RESTATEMENT (THIRD), supra note 8, § 458(1) ("provided that the courts of that State would have jurisdiction over the defendant and the subject matter of the claim if the defendant were not a foreign state"). But see H.R.ReP. No. 94-1487, at 27 (1976), reprinted in 1976 U.S.C.C.A.N. 6604, 6626 ("section 1330(b) of the bill confers personal jurisdiction over a foreign state in Federal and State courts as to every claim for which the foreign state is not entitled to immunity"). If so, however, that is not to deny constitutional power. "By reason of its authority over foreign commerce and foreign relations, Congress has the undisputed power to decide, as a matter of federal law, whether and under what circumstances foreign nations should be amenable to suit in the United States.” Verlinden B.V. v. Central Bank of Nigeria, 461 U.S. 480, 493 (1983).

In the process of reaching compromises with delegates from other countries, the American delegates would do well to remember that due process is a floor and, thus, that there is room to live above it. They might also find it easier to accept that, when one views the United States as the relevant territory, there is no need to insist on the availability of every basis of jurisdiction to adjudicate found in the law of the fifty states and/or found not to violate due process, and conversely, no need to resist a single basis that might violate due process if asserted by a state court. If the time comes to consider whether to adopt compromises made at The Hague as federal law, the same perspective should ease the burdens of those concerned about either the legal or the political problems of federalism.

Burbank, supra note 6, at 114-15 (footnotes omitted). See Kevin M. Clermont, Jurisdictional Salvation and the Hague Treaty, 85 CoRneLl L. REv. 89, 124-29 (1999). The question of congressional power to preempt state subject matter jurisdiction is analytically distinct. See, e.g., Anthony J. Bellia, Jr., Congressional Power and State Court Jurisdiction, 94 GEO. L.J. 949 (2006). 
of a treaty) could rationally regard the regulation of jurisdiction as a necessary and proper means to elicit desired action on judgment recognition and enforcement by other States.

That the federal government has the constitutional power to displace state law in the territory covered by the Hague Convention does not mean that such power should be exercised. Whether in response to the Hague Convention or to the ALI's proposed federal foreign-country judgment recognition and enforcement statute, one hears claims that, because state law has dominated the American jurisdiction and judgments landscape in international cases to date, it should continue to do so. The relationship between federal and state law in both parts of this jurisprudential landscape is, however, more complex than these claims acknowledge. Indeed, in neither part of the landscape does a consideration of past practice yield a persuasive normative argument for state law to continue to play the dominant role.

In considering the normative implications of the history of foreign-country judgment recognition and enforcement practice in the United States, it is important, first, to see that history clearly, and, second, to take account of both the influences contributing to it and changes in the relevant environment. As to the history, given the widespread and abiding influence of Hilton v. Guyot, ${ }^{40}$ a realist would have to agree that, to a considerable extent, federal law continues to rule from the graveyard of the general common law. ${ }^{41}$ Thus, the 1962 Uniform Act was not primarily a response to perceived problems of lack of uniformity. It was instead an attempt to address difficulties encountered by those seeking recognition and enforcement of American judgments abroad that were thought to arise from the form of American law. The hope was that the familiarity of codified law would ease the path of foreign courts bound to satisfy themselves that reciprocity would be accorded here. ${ }^{42}$ Of course, the perception thirty years later that the Uniform Act had not proved adequate to that task, among other reasons, led the United States to initiate the effort that ultimately yielded the Hague Convention. $^{43}$

${ }^{40} 159$ U.S. 113 (1895).

${ }^{41}$ See Burbank, Federal Judgments Law, supra note 4, at 1574 (Hilton "has been a fertile source of rules, leading to the substantial measure of uniformity that was the great hope, oft defeated, of the author of Swift v. Tyson") (footnotes omitted); id. at 1580 ("it was ... the existence of such uniform judge-made rules, albeit in different garb, that largely explains the current state of recognition law"). See also Louise Ellen Teitz, The Story of Hilton: From Gloves to Globalization, in CIVIL Procedure StORIES 427, 447-48 (Kevin M. Clermont ed., 2004).

${ }^{42}$ See Burbank, Federal Judgments Law, supra note 4, at 1575-76; Adolph Homburger, Recognition and Enforcement of Foreign Judgments: A New Yorker Reflects on Uniform Acts, 18 AM. J. CoMP. L. 367, 369-70 (1970); Barbara Kulzer, Recognition of Foreign Country Judgments in New York: The Uniform Foreign Money-Judgments Recognition Act, 18 BufFALO L. REV. 1, 5 (1968-69).

${ }^{43}$ See Ronald A. Brand, Enforcement of Foreign Money-Judgments in the United States: In Search of Uniformity and International Acceptance, 67 NoTRE DAME L. REV. 253, 283 (1991).

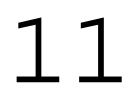


Historical perspective on the law governing foreign-country judgments also requires attention to the fact that, while federalism was taking a beating at home in diversity litigation when federal courts ignored state common law under the authority of Swift v. Tyson, ${ }^{44}$ isolationism and arguments about state prerogatives combined to prevent the United States from joining the Hague Conference, and thus from participating in any private international lawmaking (including earlier conventions on the recognition and enforcement of judgments), until $1964{ }^{45}$

As to the environment in which foreign-country judgment recognition and enforcement questions arise, changes in the scope of international commerce and in the incidence of international disputes requiring resolution prompted the United States finally to overcome federalism objections and ratify the New York Convention (and Congress to enact implementing legislation) for arbitration agreements and arbitral awards. ${ }^{46}$ Congress also determined that the problems of international litigation warranted a federal response, ${ }^{47}$ and once having joined the Hague Conference, the United States promptly ratified the Hague

${ }^{44} 41$ U.S. (16 Pet.) 1 (1842). This decision authorized federal courts independently to "find" the governing rules - and thus not to follow the law as prescribed by state supreme courts - in cases where the federal government as a whole lacked constitutional authority to make law. It was overruled in 1938.

${ }^{45}$ See Burbank, supra note 5, at 104, 128, 135, 138.

${ }^{46}$ See Convention on the Recognition and Enforcement of Foreign Arbitral Awards, June 10, 1958, 21 U.S.T. 2517, 330 U.N.T.S. 3; Pub. L. 91-368, § 1, 84 Stat. 692 (codified at 9 U.S.C. §§ 201-08 (2000)).

We maintained an isolationist position in the field of private international law long after we had abandoned this ostrich posture in the public law area. For example, as late as 1958 the United States delegation to the United Nations Conference on International Commercial Arbitration, because of the traditional concern regarding federal-state relations, was under instructions not to participate actively in formulating a convention for the recognition of foreign arbitral awards. After the conference adopted such a convention, the delegation recommended against our adherence thereto on the ground, among others, that the United States lacked a sufficient domestic legal basis for acceptance of an advanced international convention on the subject of arbitration. This always struck me as making us out even more backward than we were.

Richard D. Kearney, The United States and International Cooperation to Unify Private Law, 5 CORNELL INT'L L.J. 1, 2 (1972) (footnote omitted).

${ }^{47}$ See Act of Sept. 2, 1958, Pub. L. 85-906, 72 Stat. 1743 (establishing Commission and Advisory Committee on International Rules of Judicial Procedure). For the work of this commission, see Burbank, supra note 5, at 107-11.

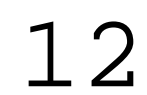


Service Convention and stimulated and ratified the Hague Evidence Convention, selfexecuting treaties that address some of those problems. ${ }^{48}$

In considering both the history and changed circumstances of foreign-country judgment recognition and enforcement practice in the United States, it is worth recalling that the framers (and ratifiers) of the Constitution believed that federal control of interstate judgment recognition and enforcement practice was important to the development of an efficient national economy. Almost two hundred years later, those responsible for the Brussels Convention came to a similar conclusion about the importance of uniform (jurisdiction and) judgment recognition standards to the European Economic Community/European Union. ${ }^{49}$ In this light, and now that the United States, no longer isolated (at least commercially), seeks to compete in a global economy, the normative case for federal leadership in international judgment recognition and enforcement practice would appear at least as strong today as was the case for federal control of interstate practice in 1787. In particular, the interests of U.S. participants in the global marketplace would be well served by uniform international standards for the recognition and enforcement of U.S. judgments in other nations and of foreign-country judgments in the United States.

Realism, historical perspective, and attention to changed circumstances are also useful when considering the respective roles of state and federal law in prescribing jurisdiction standards for international cases. Moreover, here too it is helpful to assess federalism claims with attention to wholly domestic cases. Doing so reveals that direct federal constitutional control of state law was for many years an impediment to the development of jurisdiction standards adequate to the needs of a changing society, and in particular of a national economy. ${ }^{50}$ Since 1945, however, federal constitutional law has been the prime legal engine of change, prompting some state courts simply to ignore statutory language that would restrict jurisdictional reach permitted by due process, and some state legislatures explicitly to link state to federal constitutional law. ${ }^{51}$

${ }^{48}$ See Burbank, supra note 5, at 129-35.

Those who framed the Brussels Convention realized, as did the framers of the Full Faith and Credit Clause of the United States Constitution, that civil courts can be instruments of economic warfare and, conversely, that shared judgment recognition standards can be powerful facilitators of economic cooperation and integration.

Burbank, Jurisdictional Equilibration, supra note 4, at 204 (footnotes omitted).

${ }^{50}$ See Pennoyer v. Neff, 95 U.S. 714 (1878); Geoffrey C. Hazard, Jr., A General Theory of State-Court Jurisdiction, 1965 SuP. CT. REV. 241.

${ }^{51}$ See Int'l Shoe Co. v. Washington, 326 U.S. 310 (1945); Burbank, Jurisdictional Equilibration, supra note 4, at 210; Burbank, supra note 6, at 113-14, 118: Stephen B. Burbank, All the World His Stage (book review), 52 AM. J. CoMP. L. 741, 744-45 (2004). 
The transformation of due process from a jurisdictional floor into a bed has not been costless in domestic cases. Moreover, the same incentives and dilemmas that incline states to race to the bottom in the domestic dispute resolution market also operate in the global dispute resolution market that brings the world into our courts. ${ }^{52}$ Direct federal constitutional control of the states' reactions to those incentives may be adequate to ensure the "great care and reserve" that, the Supreme Court has told us, is necessary in exercising jurisdiction in international cases generally. ${ }^{53}$ The question, however, is whether such federal power in reserve is adequate for the purpose of devising a credible and efficient system to ensure that we honor an international agreement in which jurisdiction is the critical quid for a recognition and enforcement quo.

\section{The Form and Content of Implementing Law}

I assume that there is no serious interest in putting to the test the domestic constitutional question, noted by Professor Reitz, whether implementation of the Hague Convention could be left to some process of choice by the states ${ }^{54} \mathrm{I}$ also assume consensus on the proposition that both the utility of the Hague Convention standing alone and its utility as a prelude to renewed negotiations for a more inclusive treaty ${ }^{55}$ depend to a considerable extent, both here and abroad, on its effectiveness within most if not all of the states of the United States. On those assumptions the choice of both the means of implementation and the supplementary rules to use as implementing law turns on an assessment of the respective costs and benefits of (1) uniform federal law and (2) state law operating under federal control.

So defined the problem is analytically similar to that of determining the source of rules for judge-made law in areas of federal lawmaking competence. Erie R.R. v. Tompkins ${ }^{56}$ ushered in a period of uncritical exuberance for a species of federal common law that was consistent with a newly discovered attention to state lawmaking prerogatives - during which the Supreme Court leaped both from a conclusion of federal lawmaking competence to that of

${ }^{52}$ See Stephen B. Burbank, Jurisdictional Conflict and Jurisdictional Equilibration: Paths to $a$ Via Media?, 26 Houston J. InT’L L. 385, 393 (2004).

${ }^{53}$ Asahi Metal Indus. Co. v. Superior Court, 480 U.S. 102, 115 (1987).

${ }^{54}$ See supra text accompanying note 29.

Some proposed "federal-state clauses" would permit a federal state to leave implementation to its constituent units, incurring no violation of international obligation if implementation fails. Even without a special provision, a federal state may leave implementation of its international obligations to its constituent units, but the central government remains responsible if the obligation is not fulfilled.

RESTATEMENT (ThIRD), supra note 8, § 302 rptrs. note 4. See id. § $321 \mathrm{cmt}$. b.

${ }^{55}$ See Burbank, supra note 52, at 403; Ronald A. Brand, Current Problems, Common Ground, and First Principles: Restructuring the Preliminary Draft Convention Text, in A GLOBAL LAW OF JURISDICTION AND JUDGMENTS, supra note 6, at 75, 77.

${ }^{56} 304$ U.S. 64 (1938).

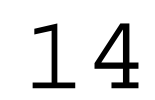


federal judicial lawmaking competence and from the latter conclusion to uniform federal judge-made rules. ${ }^{57}$ In due time, however, the Court began to look critically at appeals for uniformity and, particularly in areas implicating reliance on state law for abutting or intersecting norms, to "borrow" state law as federal law. ${ }^{58}$ On issues lacking a persuasive case for uniformity and/or portending the disruption of expectations founded on state law, this approach prefers ex post policing of aspects of borrowed state law that are hostile to or inconsistent with federal interests to ex ante specification of uniform federal rules.

Professor Reitz’s main concern relates to what he calls “international private law,” rather than private international law -- to substantive law rather than the law of procedure. ${ }^{59}$ It is therefore not apparent why he lumped the putative Hague Convention with efforts to conclude treaties on matters of substantive law. ${ }^{60}$ For, it is not difficult to imagine the confusion and disruption of legitimate expectations that could flow from superimposing federal (i.e., treaty) substantive law norms for international cases on domestic state law that would otherwise govern such matters. ${ }^{61}$ Uniformly federal jurisdiction and judgment recognition and enforcement law for international cases would not usually seem to present a comparable problem. Nor does the existence of the Uniform Foreign-Country Money Judgments Recognition Act, presumably the "existing product of the Uniform State Laws Conference" to which Professor Reitz refers in connection with the Hague Convention, ${ }^{62}$ implicate the kind of planning or reliance interests that ground his justifiable concern.

${ }^{57}$ See, e.g., Clearfield Trust Co. v. United States, 318 U.S. 363 (1943); Stephen B. Burbank, Interjurisdictional Preclusion, Full Faith and Credit and Federal Common Law: A General Approach, 71 CORNELL L. REV. 733, 758 (1986).

${ }^{58}$ See, e.g., United States v. Kimbell Foods, Inc., 440 U.S. 715 (1979); Burbank, supra note 57 , at 758 .

${ }^{59}$ See Reitz, supra note 28, at 303 n.7, 304-05.

${ }^{60}$ See id. at 327; supra text accompanying notes 35-36.

61 Conventions that provide substantive laws, even when restricted in scope by an internationality factor, may nonetheless fit uncomfortably alongside domestic laws. If internationality is established merely by international diversity of residence or citizenship of parties to transactions or events, the conventions may fall on the domestic side or on the international side by virtue of facts that were not perceived as having major legal significance to the actors at the time transactions were agreed to. The substantive content of a convention however, may differ very significantly from the substantive content of domestic law.

Id. at 315. See id. at 316.

${ }^{62}$ See supra text accompanying note 36 . It is interesting both that the Uniform Commissioners approved a Model Choice of Forum Act in 1968 and that their action in doing so was described as reflecting "the thought that the Commissioners could play a useful role in transmuting certain conventions prepared by the Hague Conference into uniform, or model, acts.” Willis L. M. Reese, The Model Choice of Forum Act, 17 AM. J. CoMP. L. 292, 292 (1969). However, the relevant convention, the Convention of 25 November 1965 on the

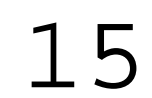


Professor Reitz also lumped the putative Hague Convention with other putative treaties in arguing that the prospect of state involvement in implementation could help to shape the negotiations, perhaps permitting a choice of "soft law" over "hard law," and in any event of a treaty that would not be deemed self-executing. ${ }^{63}$ In fact, however, the Hague Convention had taken almost final shape when he wrote his article, and both the subject matter and the history of the negotiations suggest that a quest for "soft law" would have been a non-starter. It is no surprise that the Hague Convention looks like a self-executing treaty. The quest for uniformity and certainty - for reciprocity -- that animated the treaty left little room for variation or departure.

If, then, the implementation of the great bulk of the Hague Convention requires uniform rules - and such rules present no threat to reliance interests founded on, and hence no occasion to harmonize, surrounding law -- it is not obvious why the United States should incur, or cause others to incur, the transaction and administrability costs of achieving that end through uniform state law rather than federal legislation. These costs would include those incurred in the federal specification (or approval) of the content of state law, together with the costs of monitoring progress in the states, and, perhaps, of devising and triggering a federal legislative default in the event of recalcitrance. They also would include the time and trouble of securing passage of uniform legislation in the states, twenty of which do not presently follow any version of the uniform act for foreign-country judgments, and the costs to contracting parties and disputants, here and abroad, in figuring out what United States law is. ${ }^{64}$ Finally, some of these costs would recur if it were necessary to respond to international developments by changing the governing law.

To require implementation by state law in these circumstances might well seem "a mere token gesture achieved at the expense of ... economy." "65 Alternatively or in addition, it

Choice of Court, never entered into force, see http://www.hcch.net/index_en.php?act=conventions.status\&cid=77, and the Model Choice of Forum Act was withdrawn in 1975 because of its limited adoption (two states as of 1975) and also because of "other considerations," including constitutional concerns in light of D.H. Overmyer Co. v. Frick Co., 405 U.S. 174 (1972). See 84 HANDBOOK OF THE NATIONAL CONFERENCE OF COMMISSIONERS ON UNIFORM STATE LAWS 142 (1975).

63 See Reitz, supra note 28, at 326-27.

${ }^{64}$ See Walsh v. Ford Motor Co., 807 F.2d 1000, 1016 (D.C. Cir. 1986), cert. denied, 482 U.S. 915 (1987) (noting that the Uniform Commercial Code "is not uniform"). Domestic accessibility should not be a problem for federal law prescribed by statute rather than selfexecuting treaty. See Burbank, supra note 5, at 131 ("More than twenty years have passed since the United States ratified the Service Convention, and we are just now seeking to clear up part of the mess that has been spawned in domestic litigation by ignorance of the treaty and uncertainty as to whether and when it is binding.”) (footnote omitted).

${ }^{65}$ Gjellum v. City of Birmingham, Ala., 829 F.2d 1056, 1064 (11 ${ }^{\text {th }}$ Cir. 1987). 
might be regarded as another manifestation of the United States' willingness to undermine treaties by preferring domestic to international uniformity. ${ }^{66}$

On this view, the strongest argument for implementation of the Hague Convention by a process that relies on state lawmaking rests on a claim that state law should govern those few matters on which the treaty contemplates (or tolerates) disuniformity. As mentioned above, those matters include: (1) rules for determining when a choice of court agreement covered by the Hague Convention is "null and void," (2) rules for determining the capacity to conclude a choice of court agreement covered by the treaty, (3) public policy norms that would be violated by giving effect to choice of court agreements covered by, or by recognizing and enforcing the judgments of courts exercising jurisdiction pursuant to, the Hague Convention, and (4) principles as to service of process and of "procedural fairness" that are deemed to be "fundamental." ${ }^{67}$ If a Contracting State with a non-unified legal system can make declarations on behalf of fewer than all of the constituent states to which the treaty extends, one should also consider whether state choice is appropriate as to those matters. ${ }^{68}$

Before considering the implications for domestic law of these few matters of choice that the Hague Convention leaves to Contracting States, it is important to make explicit what has thus far only been suggested: there is no necessary connection between the process used to implement the treaty and the source of the rules to which resort is made for that purpose. A conclusion that state law, borrowed as (or operating by grace and under the supervision of) federal law, should govern some (or even all) of those matters would by no means entail a conclusion that implementation should be left to state legislation, uniform or otherwise. ${ }^{69}$

${ }^{66}$ See Burbank, supra note 5, at 135-39, 149-50. Note that prolonged delay in the implementation of the Hague Convention should itself be considered a cost for this purpose. See infra text accompanying note 106.

67 See supra text accompanying notes $17-22$.

${ }^{68}$ See supra text accompanying notes 23-27. I doubt that the language, purposes and drafting history of the Hague Convention would support a conclusion that such power exists. Declarations aside, I assume agreement that the choice of a rule on translation of required documents for purposes of Article 13(4) should be made on behalf of the United States as a whole.

69 The likelihood that affording scope to the operation of state law on some matters would lead to domestic choice of law questions, the potential for uniform answers to which might best be provided by federal choice of law rules (specifying state law), may itself be an argument against implementation through state legislation. One's view on that question probably depends on one's view about which implementation process - federal legislation or the uniform state law process - is most likely to lead to choice of law rules that best respect both state interests and the interests of the United States. Such questions are apart from the international choice of law questions implicated in the fact that, for instance, "law of the State" in Article 5(1) apparently "includes the choice-of-law rules of that State as well as its rules of internal law.” DoGAUCHI \& HARTLEY, supra note 16, at 22. See Teitz, supra note 1, at 550.

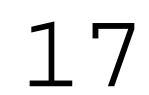


Indeed, if federal legislation is deemed necessary for any purpose in connection with the implementation of the Hague Convention, that provides an additional argument against partial reliance on implementation through state legislation. Overcoming congressional inertia in matters of private international law is not easy, and if federalism values can be adequately protected without incurring the additional and potentially very substantial costs of legislation in the fifty states that are discussed above, it would make little sense to eschew the costminimizing strategy.

The Hague Convention appears to present the possibility of using state law to achieve the goal, adduced by Professor Reitz, of harmonizing treaty law with surrounding state law. As previously noted, jurisdiction and judgments law in general do not usually prompt the concerns, such as undermining reliance interests, that animate the impulse to harmonize. The Hague Convention is different because its sole jurisdictional basis implicates substantive contract law, in particular the law governing the validity of, and the capacity to enter into, contracts. The two issues warrant separate treatment for these purposes.

It is, of course, true that state law governs most domestic contracts and hence the question whether any particular domestic contract is "null and void." It is also true, however, that the contract issues presented by choice of court clauses are not currently governed by uniform state law. Indeed, recent scholarship suggests that contract issues have been widely neglected in the choice of court clause context, with attention focused on the "conflicts issues" - the question whether, assuming that the parties entered into a valid contract to select a forum, it should be enforced. ${ }^{70}$ The Hague Convention leaves no room (among Contracting States) for choice on the "conflicts issues," specifying as the only such grounds for nonenforcement that (1) "giving effect to the agreement would lead to a manifest injustice or would be manifestly contrary to the public policy of the State of the court seised," and (2) "for exceptional reasons beyond the control of the parties, the agreement cannot reasonably be

${ }^{70}$ See William J. Woodward, Jr., Finding the Contract in Contracts for Law, Forum and Arbitration, 2 HAstings Bus. L.J. 1 (2006). Because the "contract issues" may involve a conflict of laws, it might be better to frame the dichotomy as one between "contract issues" and "enforcement issues," but I will follow Professor Woodward's terminology. One cause of the failure to distinguish between the "contract issues" and the "conflicts issues" may have been the fact that the Supreme Court's decision in the M/S Bremen v. Zapata Off-Shore Co., 407 U.S. 1 (1972), which had enormous influence on federal (outside of the admiralty context) and state law, involved a choice of court clause in a negotiated contract between sophisticated repeat players. Cf. Woodward, supra, at 34 (choice of law clauses). For the influence of M/S Bremen, see Comment, Recent International Agreement, 119 HARV. L. REV. 931, 936 (2006); Jason Webb Yackee, Note: A Matter of Good Form: The (Downsized) Hague Judgments Convention and Conditions of Formal Validity for the Enforcement of Forum Selection Agreements, 53 DUKE L.J. 1179, 1184-90 (2003).

\section{8}


performed."71 Moreover, experience in a cognate area suggests that harmonization of the law governing choice of court clauses with general contract law might not be a good idea.

The Federal Arbitration Act provides that arbitration agreements "shall be valid, irrevocable, and enforceable, save upon such grounds as exist at law or in equity for the revocation of any contract."72 The Supreme Court has interpreted this provision as requiring that states treat arbitration clauses no differently than other contracts, or, put otherwise, as depriving states of the power to apply special contract rules to arbitration clauses in gross or to address perceived problems arising in specific contexts where contracts to arbitrate are found. ${ }^{73}$ The Court's decisions have led either to a failure of regulation or to a very small tail wagging a very large dog. ${ }^{74}$ In the latter regard, the temptation is strong for state courts that seek to protect "those who are predictably disadvantaged where the likelihood of such disadvantage is plain for all to see"75 to pretend that they are faithfully applying to arbitration clauses general contract doctrines such as unconscionability. ${ }^{76}$

This experience under the Federal Arbitration Act suggests that viewing the Hague Convention as an opportunity to harmonize those contract issues that it leaves to domestic law with the general law of contracts of the states of the United States might be a mistake. ${ }^{77}$ Moreover, when considered with the underdeveloped condition of the (state and federal) law concerning contract issues presented by choice of court clauses, it inclines me to the view that international choice of court agreements should be treated discretely. The general contract issues are not, in any event, currently governed by uniform state law, which is another way of saying that the strongest argument for making some use of state law in the implementation of

${ }^{71}$ Hague Convention, supra note 1, art. 6(c) \& (d). The treaty does, however, leave room for choice within a Contracting State that is a non-unified legal system. For the law that should govern "public policy" questions, see infra text accompanying notes 95-98.

72 U.S.C. § 2 (2000).

73 See, e.g., Doctor's Associates, Inc. v. Casarotto, 517 U.S. 681 (1996); Perry v. Thomas, 482 U.S. 483, 490-91, 492 n.9 (1987); Southland Corp. v. Keating, 465 U.S. 1, 10-12 (1984).

${ }^{74}$ See Burbank, supra note 52, at 393-94.

${ }^{75} \mathrm{Id}$. at 393.

${ }^{76}$ In a very interesting paper, Stephen Broome uses empirical and doctrinal evidence to argue that the California courts, while purporting to apply general unconscionability doctrine to arbitration clauses, "routinely apply an entirely different test, requiring less of parties seeking to avoid arbitration.” Stephen A. Broome, An Unconsionable Application of the Unconscionability Doctrine: How the California Judiciary is Circumventing the Federal Arbitration Act 2 (unpublished paper available from author).

${ }^{77}$ See Kubis \& Perszyk Associates, Inc. v. Sun Microsystems, Inc., 146 N.J. 176, 197, 680 A.2d 618, 628 (1996) ("Nor does our holding in any respect undermine the interests served by enforcing contracts freely negotiated by responsible parties with comparable bargaining power. We simply acknowledge that the vast majority of franchise contracts do not fit within that category.”). 
the Hague Convention speaks more clearly to the source of rules to supplement, than it does to the mode of implementing, the treaty.

Although the Hague Convention tolerates divergence on issues of validity among Contracting States, and also within States having non-unified legal systems, the prospects of achieving international uniformity through rapprochement ${ }^{78}$ are obviously greater when the United States speaks with one voice than when it speaks with fifty. Both antecedent neglect of the issues and the context in which they arise are evidence against an argument that the use of federal law for this purpose would damage reliance interests or upset expectations. Together with the absence of an existing uniform act governing the contract issues, they are also evidence against an argument for implementation through state legislation. The goals of certainty and accessibility also favor uniform federal rules on validity issues, ${ }^{79}$ while the inapplicability of the Hague Convention to choice of court clauses in consumer and employment contracts reduces the likelihood of policy conflict in selecting the rules. ${ }^{80}$ Particularly in light of (1) the considerations that favor discrete treatment of the contract issues underlying choice of court clauses that are canvassed above, and (2) the opportunity for parochial behavior that remitting such issues to state law for international choice of court clauses would present, ${ }^{81}$ the case for federal law seems quite powerful. It becomes stronger still when one considers the potential costs of federal monitoring of borrowed state validity law.

To say that uniform federal law should govern whether a choice of court clause that designates a U.S. court under the Hague Convention is "null and void" is not to say that the federal legislation so providing would or should seek to do so at a high level of specificity. Rather, the legislation should specify the circumstances in which U.S. law will be applied to such a clause (a uniform federal choice of law rule) and the grounds upon which, viewed as a contract, such a clause can be deemed "null and void" under U.S. law - such as lack of

${ }^{78}$ See Burbank, supra note 52, at 403-04.

${ }^{79}$ See Burbank, Federal Judgments Law, supra note 4, at 1586-87 (arguing "in favor of checks provided by uniform federal law”). Recall that, under Articles 6 and 9, the task of ascertaining and applying the relevant U.S. law will fall to the courts of other Contracting States when a U.S. court is the "chosen court." See supra text accompanying notes 18-19.

${ }^{80}$ It is true, however, that the Hague Convention's definition of a "consumer" is quite narrow. See Hague Convention, supra note 1, art. 2 (1)(a) ("a natural person acting primarily for personal, family or household purposes"); Woodward, supra note 70, at 27. "The definition is also certainly not coextensive with the range of adhesion contracts. A dentist buying software for her practice is functionally no different from a 'consumer' when it comes to being bound by a click-to-agree choice-of-forum clause contained within license terms that may or may not be available in advance.” Id. at $27 \mathrm{n} .84$.

${ }^{81}$ An obvious opportunity for such behavior lies in manipulating choice of law doctrine to apply domestic law, which is a reason, apart from the goal of uniformity, why federal choice of law rules should apply. See supra note 69.

\section{0}


assent, $^{82}$ mistake, misrepresentation, fraud, and unconscionability - leaving it to the courts, federal and state, to work out how those grounds should be formulated in the specific context of international contracts governed by the treaty. The decisions of those courts would be subject to review by the Supreme Court of the United States. They would thus be akin to the "conflicts issues," the standards governing which are specified in Article 6 of the treaty, and the state and federal court decisions applying which will raise a question of federal law subject to the Court's review. ${ }^{83}$

This proposal contemplates, in other words, a level of statutory specificity akin to that which characterizes uniform acts, and it therefore contemplates a comparable degree of space within which courts have the freedom to flesh out the specified norms. The important differences between the two regimes are that norms specified in, and elaborated pursuant to, federal legislation are indisputably federal, and that the Court is available to monitor developing law and address conflicts in decisions below. It is not clear, on the other hand, how federal monitoring of a uniform act relied on to implement the Hague Convention would work either in theory or practice. Moreover, although the borrowed nature of (non-uniform) state law to which federal implementing legislation might refer discrete issues would be clear, "ex post policing” of fifty state laws, if taken seriously, would likely be more costly for litigants and courts (including the Supreme Court) than would a regime of uniform federal statutory norms elaborated by the Court through a few strategically timed decisions. Finally in this aspect, since the treaty itself specifies, and federal law will therefore govern, most of the norms to determine the "conflicts issues," 84 splitting implementing law between federal and (borrowed) state law risks undue complexity and confusion and hence failure to "devis[e] a credible and efficient system to ensure that we honor an international agreement in which jurisdiction is the critical quid for a recognition and enforcement quo." 85

${ }^{82}$ The Hague Convention provides that "an exclusive choice of court agreement must be concluded or documented - (i) in writing; or (ii) by any other means of communication which renders information accessible so as to be usable for subsequent reference." Hague Convention, supra note 1, art. 3(c). Satisfaction of these formal requirements of validity should not foreclose a challenge to the validity of a choice of court clause predicated on a lack of assent. See Teitz, supra note 1, at 552 (Hague Convention contains "nothing on substantive validity"). For the relationship between the two in United States and European Union law, see Yackee, supra note 70, at 1192-1204.

${ }^{83}$ See supra text accompanying note 71 . But see infra text accompanying note 95-98 (public policy). On the assumption that, even without any new grant of jurisdiction, most cases governed by the Hague Convention would be within the subject matter jurisdiction of the federal courts, I would not expect many of them to be filed, or remain, in state courts.

${ }^{84}$ See supra note 71; infra text accompanying notes 95-98.

85 Supra text following note 53. If the source of rules for the contract issues and the conflicts issues were separated, it seems less likely that the Court would (at last) develop an approach to choice of court clauses that attends coherently to both, which approach might then be applied in domestic cases. Note, however, the argument that some public policy norms 
Some of the considerations adduced in favor of uniform federal law (including federal choice of law) for the validity issues arising in connection with choice of court clauses subject to the Hague Convention, including the argument concerning complexity and confusion as a result of multiple sources of rules, are equally applicable to the ground, in Articles 6 and 9 of the treaty, that "a party lacked the capacity to conclude the agreement."86 Given, however, that (1) there is no evidence of special capacity rules for choice of court clauses in state law and no evidence of a developed federal law of capacity to contract, and (2) the lack of capacity that would defeat such a clause is thus likely also to defeat the contract of which it is a part, even though treated as separate under the Hague Convention ${ }^{87}$ there is here a plausible argument that a different standard would unreasonably upset justifiable reliance interests. ${ }^{88}$ On this view, the need is for federal choice of law rules specifying what State's law applies on issues of capacity, and, when United States law applies, what state's law governs.

Finally in this aspect, experience shows that the other major contract law issues raised in connection with international choice of court clauses -- questions of interpretation -concern whether they are exclusive or non-exclusive and their scope. ${ }^{89}$ Both issues are addressed in the Hague Convention, ${ }^{90}$ and questions relating to them should therefore be answered as a matter of uniform federal law. Uniform federal law should also govern the

should be non-uniform because derived from varying state laws. See infra text accompanying notes 95-98.

${ }^{86}$ It may be that lack of capacity, which is not mentioned in Article 5, is nonetheless subsumed within the grounds on which a chosen court might deem a choice of court clause "null and void" under that article. See DOGAUCHI \& HARTLEY, supra note 16, at 22 n. 91, 28.

${ }^{87}$ See Hague Convention, supra note 1, art. 3(d) (“an exclusive choice of court agreement that forms part of a contract shall be treated as an agreement independent of the other terms of the contract. The validity of the exclusive choice of court agreement cannot be contested solely on the ground that the contract is not valid.”).

${ }^{88}$ Because the relevant state law is not contained in a uniform act, and because in any event we are now talking about only one of scores of legal issues under the Hague Convention, almost all of which either must or should be governed by federal rules, a conclusion that state law should be borrowed hardly entails a conclusion that implementation should come by way of state legislation.

${ }^{89}$ See GARy B. Born, InTERnational Civil Litigation in United States Courts 454-57 (3d ed. 1996).

${ }^{90}$ See Hague Convention, supra note 1, art. 3(b) ("a choice of court agreement which designates the courts of one Contracting State or one or more specific courts of one Contracting State shall be deemed to be exclusive unless the parties have expressly provided otherwise"); id. art. 3(a) ("for the purpose of deciding disputes which have arisen or may arise in connection with a particular legal relationship"). 
remedies, if any, that are available for breach of a valid choice of court clause that is governed by the Hague Convention. ${ }^{91}$

Turning to the other matters possibly suggesting a choice of state law, if not of implementation through state legislation, as a normative matter it is difficult to argue that the "fundamental principles" referred to in connection with service of process should be different from those animating federal due process limits (i.e., adequate notice and opportunity to be heard) to which state law is already subordinate in wholly domestic proceedings. ${ }^{92}$ As suggested by the Supreme Court's cautions against parochialism in Hilton v. Guyot, ${ }^{93}$ however, both due process and state law might be unreliable sources of "fundamental principles of procedural fairness" for international purposes. Hilton itself, together with the recent elaboration in the ALI draft statute and commentary, furnishes an appropriate starting place for the uniform federal standards that are best calculated to avoid parochialism and hence international friction when a foreign-country judgment is attacked on that ground. ${ }^{94}$

In the realm of "public policy," by contrast, it seems likely that different sources of rules are appropriate depending upon the territory in which the concept operates. When identifying the circumstances in which a United States court that had not been chosen by the parties could justifiably retain jurisdiction, because "giving effect to the agreement ... would be manifestly contrary to the public policy of the State of the court seised," "95 uniform federal norms are appealing because retaining jurisdiction could create a situation of actual conflict with another Contracting State through the simultaneous exercise of jurisdiction. ${ }^{96}$ Yet, those

${ }^{91}$ For example, given Article 6, consideration should be given to the question whether an injunctive or damage remedy from the chosen court because a party had brought suit in a court of another Contracting State would frustrate the smooth operation of the treaty and imperil the attainment of its objectives. This remedial question should be answered as a matter of uniform federal law. See ARTHUR TAYLOR VON MEHREN, THEORY AND PRACTICE OF ADJUDiCATORY AUTHORITY IN PRIVATE INTERNATIONAL LAW: A COMPARATIVE STUDY OF THE DOCTRINe, POLICIES AND PRACTICES OF COMMON- AND CIVIL-LAW SYSTEMS 392-401 (2003)(HAgUE ACADEMY OF INTERNATIONAL LAW, RECUEIL DES COURS, vol. 295); Louise Merrett, The Enforcement of Jurisdiction Agreements Within the Brussels Regime, 55 InT'L \& CoMP. L.Q. 315 (2006); Briggs, supra note 37, at 19-21; infra note 96. Cf. E. \& J. Gallo Winery v. Andina Licores S.A., 446 F.3d 984 ( $9^{\text {th }}$ Cir. 2006) (holding, in the absence of a treaty, that a preliminary anti-suit injunction should have been granted against foreign litigation brought in violation of a choice of court clause).

92 See Burbank, Federal Judgments Law, supra note 4, at 1586-87.

${ }^{93}$ See Hilton, 159 U.S. at 202-05.

${ }^{94}$ See Ali Project, supra note 2, § 5(a)(i); id. cmt. c; The Society of Lloyd's v. Ashenden, 233 F.3d 473, 477 ( $7^{\text {th }}$ Cir. 2000) (“international concept of due process”).

${ }_{95}^{95}$ Hague Convention, supra note 1, art. 6(c).

$96 \quad$ Congress and the President are competent to decide whether and when dismissing or staying litigation in the United States in response to, or enjoining, parallel litigation abroad, would well

\section{3}


public policy considerations are likely to be the same as the public policy considerations that would lead such a court to refuse to recognize and enforce the judgment of the chosen court. In both cases they will usually be grounded in substantive law, the source of which, in this context, will vary as between federal and state law. They are thus unlike the basic contract doctrines that determine whether a choice of court clause is "null and void," which can for this purpose be federalized without substantial cost to federalism values, and the uniformity of which is important to advance the goals of the Hague Convention. No such uniformity is conceivable, in the United States, for the many substantive law fields in which choice of court clauses subject to the treaty will operate. Moreover, "public policy" is a ubiquitous safety valve in private international law that both acknowledges limits to the quest for uniformity and lessens the incentive to manipulate other, putatively uniform, rules. ${ }^{97}$ The recently concluded work of the ALI presents a model for statutory treatment that in some situations point to state law. ${ }^{98}$

Even if the Hague Convention permits Contracting States to make (territorially) partial declarations, the predictable costs, both pre-dispute and post-dispute, of declarations that were applicable in some states of the United States and not others would be hard to justify. Surely all concerned would be better served if the United States determined for the whole country whether its courts would exercise jurisdiction when "there is no connection between that State and the parties or the dispute,"99 and whether they would refuse recognition and enforcement "if the parties were resident in the requested State, and the relationship of the parties and all

serve the nation's interests. Indeed, the fact that federal and state courts are currently making such decisions, and doing so inconsistently, is one argument for legislation as the vehicle of change. Burbank, Jurisdictional Equilibration, supra note 4, at 233.

${ }^{97}$ In this context, acknowledging a legitimate role for state law public policy norms in the application of the treaty's "conflicts issues" should reduce the incentive to manipulate those "contract issues" that, I have argued, should be governed by uniform federal law. Doing so would thus further the more general goal of "develop[ing] an approach to choice of court clauses that attends coherently to both, which approach might then be applied in domestic cases." Supra note 85. In that regard, notwithstanding the language in the New Jersey Supreme Court's Kubis decision suggesting that it was taking a different view of the "contracts issues" in the franchise choice of court context, see supra note 77, elsewhere in the opinion, that court clearly grounded its decision in public policy derived from statute. See Kubis, 146 N.J. at 19293, 680 A.2d at 626 ("enforcement of forum-selection clauses in contracts subject to the Franchise Act would substantially undermine the protections that the legislature intended to afford to all New Jersey franchisees").

${ }^{98}$ See Ali ProJect, supra note 2, § 5 (a)(vi) ("the judgment or the claim on which the judgment is based is repugnant to the public policy of the United States, or to the public policy of a particular state of the United States when the relevant legal interest, right, or policy is regulated by state law").

${ }^{99}$ Hague Convention, supra note 1, art. 19.

$$
24
$$


other elements relevant to the dispute ... were connected only with the requested State.”"100 Federal legislation should identify the relevant "State" for these purposes. In doing so, attention should be paid to the fact that other countries have used the failure to fructify federal jurisdictional power as an excuse to deny recognition to the judgments of U.S. courts. ${ }^{101}$ That is to say, in dealing with the rest of the world, the United States should take advantage of the greater reach of federal jurisdictional power, and the same perspective should guide these determinations under the Hague Convention. ${ }^{102}$

Similarly (again assuming freedom to make partial declarations), in considering the source of rules for exercising the power not to apply the Hague Convention to specific matters in which there is a strong interest, both general considerations of certainty and accessibility and the requirements that those matters be "clearly and precisely defined" and that the declaration be "no broader than necessary"103 point to a uniform federal prescription rather than state-by-state determination. ${ }^{104}$ Finally, the decision whether to extend the provisions of the Hague Convention to the recognition and enforcement of judgments given by courts designated in non-exclusive choice of court clauses, which Contracting States may do by reciprocal declarations, is a fundamental choice, arguably as significant as the decision whether to ratify the treaty, appropriate only for federal action. ${ }^{105}$

VI. Conclusion

Federalism is important in the United States. It is also important that the United States be able to participate effectively in a global economy and that those charged with the conduct of the country's foreign affairs be able to make, and that the country abide by, international agreements that are designed to facilitate transnational commercial activity. The Hague Convention is one such agreement, the modest fruits of more than a decade of work in an international lawmaking effort that was initiated by the United States. However modest the

${ }^{100}$ Id. art. 20.

101 See BAUMGARTNER, supra note 5, at 107-09.

102 See supra note 39.

103 Hague Convention, supra note 1, art. 21.

104 This provision evidently reflects risk aversion on the part of the negotiating States, given the treaty's references (in Articles 6 and 9) of questions of validity to "the law of the State of the chosen court," concerning matters that (in theory at least) could have been resolved in the treaty itself or under the public policy exception in Article 9. See Teitz, supra note 1 , at 553.

105 See Hague Convention, supra note 1, art. 22; Ronald A. Brand, The New Hague Convention on Choice of Court Agreements, http://www.asil.org/insights/2005/07/insights050726.html (last visited Nov. 28. 2005) ("If Contracting States exercise this declaration option, it will substantially expand the recognition and enforcement benefits of the Convention.”). 
fruits of the enterprise, the rest of the world is watching to see whether the United States ratifies, and how it implements, the Hague Convention. ${ }^{106}$

Effective dispute resolution processes are critical to a well-functioning global economy, and effectiveness for this purpose requires, just as it does for a national or regional economy, generous recognition and enforcement of judgments. Key to such generosity, in turn, are acceptable jurisdiction standards and, experience has demonstrated, reciprocity. Finally, mutual assurance that reciprocity will in fact be forthcoming requires very considerable uniformity and certainty in the governing legal rules.

The Hague Convention leaves little room for variation or departure in standards for asserting jurisdiction or recognizing and enforcing judgments. Although there are good reasons to implement the treaty through legislation, the proposal that the uniform state law process be used for that purpose is not well considered. The history of domestic regulation does not provide strong normative support for state law to furnish the rules for jurisdiction and judgment recognition in international cases. Harmonization with abutting or intersecting state law norms, which is a legitimate concern in thinking about international private lawmaking on many subjects, is not generally a concern in connection with the law governing jurisdiction and judgment recognition. The Hague Convention appears to be an exception to that generalization with respect to jurisdiction, because choice of court clauses implicate contract law. Experience in the arbitration field suggests, however, that an attempt to harmonize would be a mistake, and the relevant state contract law is in any event underdeveloped and not uniform. Finally, federal implementation through legislation prescribing federal law that is mostly uniform, but a few provisions of which may borrow designated state law, would impose lower transaction and administrability costs, with no loss of accessibility, than would state implementation.

${ }^{106}$ See Peter D. Trooboff, Foreign Judgments, NAT’L L.J., Oct. 17, 2005, at 13, col. 1 ("This explains why a number of the 65 member states of the Conference may await U.S. implementation of the convention before ratifying it.”). 